\title{
Social Norms and the Law in responding to Infanticide
}

\author{
Karen Brennan*
}

\section{Introduction}

“... I gave birth to a baby in a shed at the back of my house. I don't know if the baby screamed after birth... I thought the baby was dead[.] I remained in the shed about 10 minutes. There was no move from the baby and I came for a jug of water ... and baptised the baby. I took the baby from the shed and put it into a small bag and left it between the river and the roadway at the back of my house. I didn't harm the child in any way. I put the bag on the floor and laid the baby in it. I folded the bag over it then but if the baby was alive I wouldn't do that no matter what happened. I came into the kitchen then and washed myself and powdered my face.... I did not put the baby into the river. I didn't harm the baby in any way."

The above is the statement of an unmarried 22-year-old woman who, in 1953, was convicted of the recently enacted offence of 'infanticide' at the Central Criminal Court; she was discharged without sentence. ${ }^{1}$ The case is a typical example of infanticide in Ireland during the twentieth century, involving a concealed 'illegitimate' pregnancy, a secret birth, and ultimately the death of the baby.

\footnotetext{
* Karen Brennan is a lecturer in law at the University of Essex. She wishes to thank Professors Lorna Fox O'Mahony and Sabine Michalowski, and the two anonymous reviewers for their helpful and insightful comments on earlier drafts of this article.

${ }^{1}$ National Archives of Ireland (hereafter NAI): State File Central Criminal Court ID-51-2, Co Limerick, indictments no $1 \& 2,26$ October 1953. Name withheld to preserve anonymity. The offence of infanticide was created by the Infanticide Act 1949.
} 
Whilst there has been much written in recent years, particularly by social historians, about infanticide in Ireland between 1850 and 1950, the more recent experience has yet to be explored. ${ }^{2}$ This paper addresses this gap, focusing on the criminal justice response to infanticide in Ireland during the period 1924 to 2015 . $^{3}$ This allows for an assessment of the impact of social and legal changes that occurred in the second half of the twentieth century on criminal justice practice in these cases, including the enactment of the Infanticide Act 1949, and Ireland's transition from a conservative to a liberal society from the 1970s onwards. Taking account of these changing social and legal contexts, it will be argued that the Irish approach to infanticide from the time of independence and up to the present day has been based on implicit shared social norms about the 'appropriate' outcome in cases where women killed their newborn infants; the criminal law itself, though it had the potential to either impede or enable this process, had little impact on the outcome. Social norms played a vital part in the legal adjudication of these cases.

The analysis in this study highlights the importance of taking account of social norms in assessing the law and its practice, something which is relevant not only to the issue of infanticide in Ireland and elsewhere, but also to other criminal offences. ${ }^{4}$ It also demonstrates the importance of reading legal doctrine and practice through its historical, social and cultural context, showing how failure to take account of the wider non-legal

\footnotetext{
${ }^{2}$ See for example, E Farrell, 'A most diabolical deed' Infanticide and Irish Society, 1850-1900 (Manchester: Manchester University Press, 2013); C Rattigan 'What else could I do?': Single Mothers and Infanticide, Ireland 1900-1950 (Dublin: Irish Academic Press, 2012).

${ }^{3}$ This study focuses on the implementation of the Infanticide Act 1949 from charge to conviction. Sentencing under this Act is explored in K Brennan, 'Murdering Mothers and Gentle Judges: Paternalism, Patriarchy and Infanticide' (forthcoming).

${ }^{4}$ M Baier 'Relations between Social and Legal Norms' in M. Baier (ed.) Social and Legal Norms: Towards a Socio-Legal Understanding of Normativity (Surrey: Ashgate, 2013) pp 53-70.
} 
context can leave us with a deficient understanding of the law, and may even obfuscate its meaning. ${ }^{5}$

This article builds on my previous work on the criminal justice and legislative response to infanticide from the 1920s-1940s, up to the enactment of the Infanticide Act 1949. This published research has explored: the role of humanitarian and pragmatic considerations in the criminal justice and legislative response to infanticide ${ }^{6}$ practical and ideological influences on sentencing $;^{7}$ the meaning of the medical mitigation framework in the 1949 Act; and the influence of the Irish Catholic Church and its teachings on the drafting of that law. ${ }^{8}$ Whilst this earlier work indirectly touches on the issue of social norms in the response to infanticide, it does not explicitly address this matter; further, it does not consider the approach to infanticide following the enactment of the 1949 law. This article, therefore, adds another strand to the narrative of infanticide in Ireland from the time of independence from Britain, exploring for the first time the criminal justice response to maternal infant killing from 1950 onwards and explicitly focusing on the impact of the wider social context and related social norms on infanticide law and practice from the 1920s and into the twenty-first century.

Part 1 outlines the relationship between the law and society, and explains the concept of social norms, as it applies in this study. Part 2 outlines the criminal justice response to infanticide in Ireland between 1922 and 1949, drawing on my previous research on this subject and demonstrating the significance of social norms in court responses to infanticide and the enactment of the infanticide law. Part 3 presents original data and analysis of the

\footnotetext{
${ }^{5}$ R Cotterrell 'Why Must Legal Ideas Be Interpreted Sociologically' (1998) 25(2) Journal of Law and Society 171-192. See also A Norrie Crime, Reason and History: A Critical Introduction to Criminal Law, $2^{\text {nd }}$ ed (Cambridge: Cambridge University Press, 2001), ch $1 \& 2$ and passim.

${ }^{6}$ K Brennan, "A Fine Mixture of Pity and Justice:" The Criminal Justice Response to Infanticide in Ireland 1922-1949'(2013) 31(4) Law and History Review 793-841.

${ }^{7}$ K Brennan, 'Punishing Infanticide in the Irish Free State' (2013) 3(1) Irish Journal of Legal Studies 1-35.

${ }^{8}$ K Brennan, “"Traditions of English Liberal Thought:” A History of the Enactment of an Infanticide Law in Ireland' 50 (3013) Irish Jurist 100-137.
} 
criminal justice response to infanticide after the enactment of the 1949 statute, focusing particularly on the 1950s, 1960s, and early 1970s, the period when this law was most used, and demonstrating the role of social norms in the interpretation and implementation of this statute. Part 4 examines the approach to infanticide over the last four decades, a time when Irish society went through a significant liberalization process, infanticide as a crime virtually disappeared, and prosecutions for infanticide (in the rare reported case) ceased. Part 5 concludes the article.

\section{The Relationship between the Social and the Legal}

The concept of 'social norms' has theoretical, as well as popular, usage, and there is no agreed upon definition of this concept. ${ }^{9}$ It covers a broad spectrum from moral and political principles, to expectations that guide behaviour, to imperatives or requirements which may be coercive, binding and/or carry censure or sanction when breached. ${ }^{10}$ In this study, the term 'social norm' denotes the influence of the wider social context on the criminal justice response to infanticide. It embraces the idea of a generally agreed upon expectation or understanding that women who killed their newborn illegitimate babies should be treated leniently relative to other killers, something which was informed by the social context in which this crime occurred and how women who killed their illegitimate babies were, within that context, understood.

In this regard, the social and cultural context is crucial to understanding the crime of infanticide and the criminal justice response to it. Meyer and Oberman have argued: 'Infanticide is not a random unpredictable crime. Instead it is deeply imbedded in and is a

\footnotetext{
${ }^{9}$ P Koller 'On the Nature of Norms' (2014) 27(2) Ratio Juris 155-75; Baier, above n 4.

${ }^{10}$ See for example Koller, above n 9; M Svensson 'Norms in Law and Society: Towards a Definition of the Socio-Legal Concept of Norms' in M. Baier (ed.) Social and Legal Norms: Towards a Socio-Legal Understanding of Normativity (Surrey: Ashgate, 2013), pp 39-52; Baier, above n 4.
} 
reflection of the societies in which it occurs. The crime of infanticide is committed by mothers who cannot parent their child under the circumstances dictated by their unique position in place and time'. ${ }^{11}$ This is true of the Irish experience during much of the period under review in this study. At least until the 1970s/1980s, infanticide was linked to patriarchal norms and related legal prohibitions that insisted on female virtue and on motherhood within marriage. Women were denied reproductive autonomy (there was no legal access to contraception or abortion), and unmarried women who became pregnant faced significant social stigma and economic deprivation. Some women were effectively institutionalised in religious establishments. ${ }^{12}$ During this time, women prosecuted for killing their infants were usually unmarried women who had concealed pregnancy, given birth in secret and killed the baby at birth. ${ }^{13}$ Infanticide was not an uncommon crime, with 195 cases reported between 1927 and $1975 .^{14}$

Despite punitive attitudes towards unmarried mothers, there was much sympathy for the infanticide offender who was treated leniently by the criminal justice system. I have previously argued that the response was based on a tacit understanding of the circumstances involved which included acknowledgement of the wider social inequalities at play, such as the fact that the woman alone was left to bear the burden of an out of wedlock pregnancy,

\footnotetext{
${ }^{11}$ CL Meyer \& M Oberman Mothers who Kill their Children: Understanding Acts of Moms from Susan Smith to the 'Prom Mom (New York University Press: New York \& London, 2001) p 2.

${ }^{12}$ For discussion on infanticide, Irish post-independence gender ideology, and the impact of this on women (e.g. in relation to restrictions on contraception, motherhood, sexuality, and institutionalisation), see generally: Rattigan, above n 2, M Luddy, 'Sex and the Single Girl in 1920s and 1930s Ireland' (2007) 35 Irish Review 7991; M Luddy, Prostitution and Irish Society (New York: Cambridge University Press, 2007), pp 117-23, 19497, 200-3, 235-7; L Ryan, 'Irish Newspaper Representations of Women, Migration and Pregnancy outside Marriage in the 1930s' in MC Ramblado-Minero and A Perez-Vides (eds) Single Motherhood in Twentieth Century Ireland: Cultural, Historical and Social Essays (Lewiston, New York: Edwin Mellen Press, 2006), pp 105-6; M Valiulis, 'Neither Feminist nor Flapper: the Ecclesiastical Construction of the Ideal Irish Woman' in M O'Dowd and S Wichert (eds) Chattel, Servant or Citizen: Women's Status in Church, State and Society (Queen's University Belfast: Institute of Irish Studies, 1995), pp 168-78; L Earner-Byrne, Mother and Child: Maternity and Child Welfare in Dublin, 1922-1960 (Manchester: Manchester University Press, 2007), ch 7; S McAvoy, 'The Regulation of Sexuality in the Irish Free State, 1929-1935' in G Jones and E Malcolm (eds) Medicine, Disease and the State in Ireland, 1650-1940 (Cork: Cork University Press, 1999), pp 253-65.

${ }^{13}$ See generally, Rattigan, above $\mathrm{n} 2$, ch 1 .

${ }^{14}$ Central Statistics Office, 1927-1949; Garda Annual Reports on Crime, 1950-1975.
} 
the fact that the crime had taken place in the context of a concealed and unassisted birth, and the supposed (from a lay, as opposed to medical, perspective) impact of these circumstances on the woman's state of mind. ${ }^{15}$ Thus, whilst women killed their babies because of the difficulties they faced as unmarried pregnant women in a conservative and religious patriarchal society, they were, paradoxically, viewed with sympathy due to the role of these social factors in the commission of this offence.

However, sympathy was also a reflection of those same gender ideologies that contributed to the crime in the first place, and, further, evidenced a commitment to these patriarchal norms. ${ }^{16}$ Compassion, particularly when practised by prosecutors and judges, came from those in a position of authority and control over the infanticide offender, not only because of their professional status but also their gender and wider standing in society: as professional men they had the social privilege that allowed them to dole out mercy to 'unfortunate', 'poor', 'wretched' women and 'young girls' who killed their illegitimate newborn babies. However, whilst they may have had sympathy for the offender, they showed no interest in challenging the underlying gender norms that were the root cause of these inequalities; nor, was there willingness to even openly acknowledge the role of such factors. ${ }^{17}$ Indeed, the Irish infanticide law adopted in 1949, following the English model of 1938, partially excused infanticide on the ground that the woman had a 'disturbance in the balance of the mind caused by the effect of childbirth or lactation', and, therefore, on the face of it, explained infanticide as a product of mental disturbance caused by biological functions, disguising the role of wider social causes. ${ }^{18}$ Overall, the approach to infanticide, both in criminal justice practice from the 1920s onwards and in the legislation enacted in 1949, reflected a sympathetic understanding of the offender which, on the one hand, acted to

\footnotetext{
${ }^{15}$ Brennan, above n8, 122-33.

${ }^{16}$ For further discussion see Brennan, above n3.

${ }^{17}$ Ibid.

${ }^{18}$ For further discussion see below text at $\mathrm{n}$ 47-50.
} 
mitigate the harshness of social, cultural and legal norms on unmarried pregnant women, whilst, on the other hand, serving to reproduce and support the patriarchal values that contributed to those norms and this crime. ${ }^{19}$

When considering the role and impact of social norms on criminal justice practice distinctions must be drawn between the lay and professional actors involved in processing these cases. In this regard, the experience in Ireland and in other jurisdictions highlights the important function of jurors in injecting the criminal process with the socially normative view that this offender did not deserve a capital conviction. From at least the $19^{\text {th }}$ century, juries showed reluctance to convict of murder unmarried women who killed their babies at a concealed birth. ${ }^{20}$ It is jurors, therefore, their sensibilities, sense of fairness, and understanding of this offender, that is the starting point for understanding the role of 'social norms' in criminal justice practice in these cases.

Prosecutors and judges arguably had different perspectives and objectives given their position as professionals. Inglis notes there is a difference between 'the law' and those who operate it, whose own backgrounds affect their understanding and application of the law. ${ }^{21}$ However, whilst criminal justice personnel are likely to "understand and interpret the world differently to most of those who appear before the court',22 it is also true to say that as products of the culture and society in which they operate, they too likely acquiesced to some degree at least to wider 'social norms' regarding sympathetic treatment of this offender. However, as will be highlighted in the following analysis, they also operated in accordance with professional expectations of conviction and punishment. The 1949 reform, and criminal justice practice both before and after, was the product of a combination of wider social

\footnotetext{
${ }^{19}$ Brennan, above n 3.

${ }^{20}$ For English and Canadian experiences, see generally, D Seaborne Davies 'Child Killing in English Law' in L. Radzinowicz and Turner eds The Modern Approach to Criminal Law (London, 1945) pp. 301-343; KJ Kramar Unwilling Mothers, Unwanted Babies: Infanticide in Canada (Vancouver \& Toronto: UBC Press, 2005).

${ }^{21} \mathrm{~T}$ Inglis Truth Power and Lies: Irish Society and the Case of the Kerry Babies (Dublin: University College Dublin Press, 2003) p 12.

${ }^{22}$ Ibid.
} 
norms, which sought compassionate treatment, and professional norms, which sought efficiency in conviction and punishment but conceded to the socially normative expectation of lenience in this regard.

In the enactment of the infanticide statute legal norms also played a part. According to social norms lenient treatment was sought due to an understanding of the social circumstances of this crime. However, because the criminal law does not take the social context for offending into account when ascribing criminal responsibility, ${ }^{23}$ the reasons for treating this crime differently to other murders had to be moulded into a suitable mitigation framework that adhered to criminal law principles regarding individualised responsibility. ${ }^{24}$ As will be shown below, the implementation of this statute reflects the preferred response based on social norms. ${ }^{25}$ Overall, there was an interplay between social, professional, and legal norms. These blended together in the creation of the Infanticide Act, and in the way the law (on murder and infanticide) was practised. Thus, whilst the socially normative position is essential to understanding the infanticide law and criminal justice practice in these cases, it did not operate to the exclusion of other factors.

The argument that 'the social' influences the law (criminal and other laws) and its practice is of course not a new one. As Cotterrell has argued, there is no clear distinction between the legal and the social: law influences society and society influences law; we cannot understand law without taking its wider sociological context into account. ${ }^{26}$ Or, as Svensson has argued: a 'legal code by no means equals its intended practice in its implementation. The social, economic and cultural context that the law addresses in practice will also shape, contribute

\footnotetext{
${ }^{23}$ Norrie, above $n 5$.

${ }^{24} \mathrm{~T}$ Ward 'The Sad Subject of Infanticide: Law, Medicine and Child Murder 1860-1938' (1999) 8 Social and Legal Studies 163-180; Brennan, above n 8, 126-27; Kramar, above n 20, p 95.

${ }^{25}$ See below text at $65-81$.

${ }^{26}$ Cotterrell, above n 5 .
} 
to and explain its outcome'. ${ }^{27}$ Many examples in the criminal context spring to mind, such as the application of the law in cases of assisted dying where prosecutions are not always taken, ${ }^{28}$ or where criminal law doctrine with respect to the defence of diminished responsibility is stretched in a 'benign conspiracy' to facilitate a lenient outcome. ${ }^{29}$ The fact that it is expected that prosecutions will not be taken against teenagers who engage in underage consensual and non-exploitative sexual activities, despite the fact that this is illegal, ${ }^{30}$ is also another example of how social norms influence the practice of law.

This study seeks to demonstrate the application of socio-legal theory about the relationship between the social context, including social norms, and the criminal law in a specific example - that of infanticide in Ireland. It also highlights the importance of understanding the criminal law and its practice through its historic origins. ${ }^{31}$ Both legal doctrine, notably the medical mitigation rationale adopted, and criminal justice practice in the courts were affected by the wider socio-historic context. To fail to understand the socio-historic element to infanticide is to fail to understand this law.

In the following section, the criminal justice response to infanticide prior to the introduction of the Infanticide Act 1949 is examined. It will be shown how legal practice was completely at odds with the law on murder, but reflected an agreed upon lenient approach based on social norms, and how this eventually lead to legal reform to bring the law in line with practice.

\footnotetext{
${ }^{27}$ See above n 10, pp 47-8. See also Baier, above n. 4, who discusses 12 relationships of influence between legal and social norms.

${ }^{28}$ Director of Public Prosecutions, Policy for Prosecutors in Respect of Cases of Encouraging or Assisting Suicide (February 2010, updated 2014), available at: http://www.cps.gov.uk/publications/prosecution/assisted_suicide_policy.pdf

${ }^{29}$ L Kennefick 'Introducing a New Diminished Responsibility Defence for England and Wales' (2011) 74(5) Modern Law Review 750-66 at 758.

${ }^{30}$ D Omerod \& K Laird Smith and Hogan's Criminal Law (Oxford: Oxford University Press, 2015) p 868.

${ }^{31}$ Norrie, above n 5, p 8.
} 


\section{Compassionate sanction and the enactment of an infanticide law, 1924-1949.}

During the 1920s-1940s, the Irish criminal justice system consistently adopted a lenient approach to those charged with murdering their newborn illegitimate children. ${ }^{32}$ 'For motives of humanity', prosecutors avoided charging with murder, instead opting for concealment of birth, unless this was precluded by the evidence. ${ }^{33}$ Further, although 160 women appeared at the Central Criminal Court (hereafter CCC) on a charge of murdering their babies between 1924 and 1949, very few were convicted. At trial, jurors usually refused to convict of murder: only eight out of 45 women tried before a jury for murder were convicted of that offence; 26 were acquitted; 10 were convicted of a less serious offence such as manslaughter or concealment of birth; and one was found guilty but insane. Where a murder conviction did result, the death sentence was always commuted. However, most cases (70 per cent) did not proceed to trial because the state accepted a plea of guilty to manslaughter or concealment of birth. ${ }^{34}$ Sentencing of those convicted of manslaughter and concealment of birth saw very few women imprisoned, though many did, as a condition of probation or a suspended sentence, undertake a period of institutional residence at a Magdalen asylum or another convent institution. ${ }^{35}$

Overall, it is evident that it was generally accepted that women who killed their illegitimate babies at or soon after a concealed birth deserved a compassionate criminal sanction involving conviction for a less serious offence and a non-custodial or a suspended custodial sentence, which may also have included a period of religious institutionalization. This

\footnotetext{
${ }^{32}$ The criminal justice response to this offender prior to 1949 has been explored in detail elsewhere: Brennan, above $\mathrm{n} 6$. The analysis in this section presents a summary of this, and explicitly links the previous analysis, which focused on pragmatic and humanitarian influences, to the social norms framework used here. The offence of concealment of birth criminalises the concealment of the dead body of an infant following birth, whether the child died before, during or after birth. Offences Against the Person Act 1861, s. 60 (24 \& 25 Vic., cap. 100).

${ }^{33}$ NAI, DJ 8/144/1, memo dated Feb. 1949.

${ }^{34}$ Brennan, above n 6, 811-18.

35 Brennan, above n 7 .
} 
understanding of infanticide informed the criminal justice response to women charged with murdering their babies during the 1920s-1940s: the law was ignored to secure the preferred lenient outcome, and this ultimately resulted in the enactment of a specific infanticide law. ${ }^{36}$

The Infanticide Act 1949 created the new offence of 'infanticide' which was to operate as an alternative to a murder charge or conviction, carrying a flexible sentencing regime, up to a maximum of life imprisonment. ${ }^{37}$ The law did not allow for women to be charged with infanticide in the first instance, but implicitly required an initial murder charge, allowing for this to be altered to infanticide by a district justice at a preliminary hearing at the district court. ${ }^{38}$ Where the charge was reduced, the accused would be sent to the Circuit Criminal Court (hereafter CrtCC) for trial; if she was forwarded to the $\mathrm{CCC}$ on the murder charge, she could be convicted of infanticide as an alternative to murder. ${ }^{39}$ Under the provisions of the Act the offence was committed when: a woman committed a wilful act or omission that caused the death of her biological child; the child was aged under twelve months; the circumstances were such that, but for the infanticide provisions, the killing would have amounted to murder; and, finally, at the time of the killing 'the balance of [the accused's] mind was disturbed by reason of her not having fully recovered from the effect of giving birth to the child or by reason of the effect of lactation consequent upon the birth of the child'. ${ }^{40}$

The infanticide law was enacted to facilitate lenient treatment of this offence. However, whilst criminal justice agents, and eventually legislators, accepted the socially normative position that this offender should not be convicted of murder, this was balanced against

\footnotetext{
${ }^{36}$ Brennan, above n 6.

${ }^{37}$ Infanticide Act 1949, section 1.

${ }^{38}$ Infanticide Act 1949, section 1(1). For further discussion see Brennan, above n 8, 117-20.

${ }^{39}$ Infanticide Act 1949, section 1(2)

${ }^{40}$ Infanticide Act 1949, section 1. The legislation was amended in 2006 when the lactation option was replaced with a reference to a mental disorder consequent upon childbirth. Criminal Law (Insanity) Act 2006, section 22. None of the cases in this sample were disposed of under the reformed legislation.
} 
professional norms which sought conviction and punishment, and the effective administration of justice in this regard. One issue of particular concern was the waste of resources involved in sending 'wretched' women and 'young girls' to the CCC to face the 'ordeal of trial and conviction' and the 'grim spectacle' of a capital conviction which everyone, except the offender, knew would be reprieved. ${ }^{41}$ Thus, the reliance on guilty pleas prior to 1949, which excluded jurors from the decision-making process, reflects a prosecutorial commitment to lenient disposals and a determination to secure convictions in an efficient way. ${ }^{42}$ Further, as in other jurisdictions, practical issues concerning the administration of justice were an important factor in the Irish reform, particularly with regard to the efficient use of resources. ${ }^{43}$ Nonetheless, the approach taken by criminal justice professionals, and ultimately by legislators, demonstrates an acceptance of the desired outcome in these cases based on social norms. Indeed, the evidence shows there was a keen sense of compassion for this offender and a clear acceptance of the fact that she did not deserve a capital conviction. ${ }^{44}$

Thus, the criminal justice response to women who killed their babies in the 1920s-1940s, and the enactment of the 1949 infanticide statute, involved a mix of both social and professional norms. When this lead to legal change, however, the legislation was framed so as to comply with criminal law norms. The medical mitigation framework respected the criminal law's refusal to allow for mitigation based on social circumstances by ostensibly blaming the woman's imbalanced mental state and linking her crime to the effect of childbirth (or lactation). ${ }^{45}$ However, whilst the medical mitigation framework contained in the infanticide statute met the legally normative requirement of individualised responsibility,

\footnotetext{
${ }^{41}$ NAI: Department of Justice (file on infanticide) 8/144/1, letter address "Minister", dated February 1949. See generally, Brennan, above n 6, 823-26.

${ }_{42}$ Brennan, above n 6, 824-25.

${ }^{43}$ Ibid. 827-33; Davis, above n 20; Kramar, above n 20.

${ }^{44}$ See generally, Brennan, n 6, 818-33, 836-41.

${ }^{45}$ See sources cited above $\mathrm{n} 24$.
} 
it was always intended to cover the socially normative expectation that women who killed their babies because of stressful social circumstances would not be treated as murderers. ${ }^{46}$ Indeed, whilst feminists argue that infanticide laws medicalise the offender, explaining infanticide as a consequence of women's biological susceptibility to mental illness, not broader social and political inequalities, ${ }^{47}$ the history of infanticide statutes in England, Canada and Ireland, reveals that legislators did not intend to require medical diagnosis of a specific mental disorder, let alone one that had been caused by the biological event of childbirth; they incorporated a lay understanding of mental disturbance which covertly took account of the wider social factors involved. ${ }^{48}$

The background to the Irish reform shows that the mental disturbance rationale contained in the new law was supposed to cover extreme mental and emotional stress connected with giving birth to a child outside of wedlock, particularly where this occurred in the context of an unassisted birth. ${ }^{49}$ In this regard, the infanticide law embodied both social norms (namely that the woman who killed her baby at birth deserved lenient treatment in light of the mitigating social circumstances involved), and legal norms (that the socially normative expectation of lenience had to be framed so as to meet the legally normative requirement of individualized responsibility). The history of infanticide legislation demonstrates the importance of taking a socio-historical reading of the criminal law in order to fully reveal its

\footnotetext{
${ }^{46}$ For a discussion on the criminal law's requirement for individualised responsibility and the use of mental disturbance defences in this regard, see Norrie, above n 5, ch $1 \& 2$, and pp 188-96. See Brennan, above n 8 , 122-33, for further detail on the purpose and scope of the infanticide medical rationale.

${ }^{47}$ SSM Edwards Women on Trial: A Study of the Female Suspect, Defendant and Offender in Criminal Law and the Criminal Justice System (Manchester: Manchester University Press, 1984) pp 80-85 and 91-100.

${ }^{48}$ See Ward, above $\mathrm{n} 24$; KJ Kramar \& WD Watson 'The Insanities of Reproduction: Medico-Legal Knowledge and the Development of an Infanticide Law' (2006) 15 Social and Legal Studies 237-255; Brennan,, above n 8, 822-33; A Loughnan 'The Strange Case of the Infanticide Doctrine' (2012) 32 (4) Oxford J Legal Studies 685711.

${ }^{49}$ Brennan, above n 8, 122-33.
} 
meaning. ${ }^{50}$ The implementation of this statute, including how the disturbance in the balance of the mind requirement has been interpreted, will be explored in the following section.

\section{Implementing the Infanticide Act 1949}

The Minister for Justice stated when introducing the bill to the Dáil that the new law would ensure that 'in appropriate cases, it will no longer be necessary to subject unfortunate girls to the strain of undergoing a trial for murder and of being sentenced to death' ${ }^{51}$ What was meant by appropriate cases was not explicated. However, it is evident that he was referring to the typical newborn infanticide case where, according to social norms, there was no desire to convict of murder. The law allowed for a more lenient option, but there were a number of hurdles to overcome before infanticide could be used. The requirements for murder, including live birth and mens rea, must be established, ${ }^{52}$ in addition to the specific infanticide requirements outlined above. ${ }^{53}$ Further, since the law denied prosecutors the option to charge infanticide, they were reliant on district justices reducing murder charges based on the evidence produced in depositions, although they could accept an infanticide plea at the CCC. ${ }^{54}$ Arguably, the substantive legal requirements for infanticide and the procedural restraint imposed on prosecutors could have limited the extent of the application of this law. However, as will be shown in this section, the Infanticide Act operated as it was

\footnotetext{
${ }^{50}$ Cotterrell, above n 5; Norrie, above n 5.

${ }^{51}$ Dáil Debates, vol 115(2), 28 April 1949, cols 265-266.

${ }^{52}$ Infanticide Act 1949, section 1(3)(b). The Irish law contrasts with its English counterpart in this respect. See R. v. Gore (Lisa Therese) (deceased) [2007] EWCA Crim 2789; [2008] Crim. L.R. 388 (CA (Crim Div)); A Ashworth 'Infanticide: Whether Mens Rea of Infanticide Consists of an Intention to Kill or Cause Grievous Bodily Harm’ [2008] 5 Crim. L.R. 388-391.

${ }^{53}$ See above n 43.

${ }^{54}$ Infanticide Act 1949, section 1(2).
} 
meant to - as a mechanism for facilitating lenient treatment of this offender. Further it demonstrates the continued role of social norms in the application of the law. ${ }^{55}$

There were 75 reported cases of infanticide/'infant murder' between 1950 and $2015 .^{56}$ The majority of cases (60) and prosecutions took place between 1950 and 1974 inclusive. Overall proceedings were taken in 38 cases. The offender was female in 37 cases, ${ }^{57} 36$ of whom were disposed of under the infanticide law; the remaining offender was 'otherwise disposed of' on a murder charge, meaning that she was not convicted/acquitted of that offence (see Table A). There have been no recorded convictions for infanticide since 1973. This is explained by the reduced incidence of this crime, and an apparent disinclination to prosecute it: out of the 15 cases recorded for the period 1975-2015 inclusive, only four involved criminal proceedings for murder/infanticide: in three of these cases (at least one of

\footnotetext{
${ }^{55}$ The findings are based on an analysis of data in the Garda Annual Reports on Crime (1950-2005; hereafter GARC), the Central Statistics Office crime statistics (2006-2015; hereafter CSO), and on data available in state book and state file records for the CCC and CrtCC (1950s-early 1970s). The GARC provide information on the number of reported crimes, and the outcome of any proceedings initiated. Between 1951 and 1975, the GARC also provided a brief account of the circumstances of the crime and further information on the outcome of the proceedings, including the sentence imposed (Appendix D). GARC can be accessed at the National Library of Ireland, or online at: $\underline{\text { http: } / / \text { www.garda.ie/controller.aspx?page }=90}$

Information on the number of reported 'infanticide' cases since 2005, whether criminal proceedings were taken, and the outcome of those proceedings is provided by the CSO. See CSO, CJA01: Recorded Crime Offences by Type of Offence and Year, available at:

http://www.cso.ie/px/pxeirestat/Statire/SelectVarVal/Define.asp?maintable=CJA01\&PLanguage=0, accessed 23 October 2015.

The State Books for the CCC and CrtCC (hereafter SBCCC and SBCrtCC), held at the NAI, provide a record of criminal prosecutions at each court, including information on the outcome of proceedings and sentence. The State Files (hereafter SFCCC and SFCrtCC) contain documents relating to the state's case against the accused, most significantly the depositions of witnesses at the preliminary hearing of the case at the district court as well as a copy of the accused's statement(s) at the time of arrest. The NAI does not have a complete holding of these records for the period under review and a systematic investigation of each case of infanticide during this period was unfortunately not possible. There is no State Book record for the CCC from 1964 onwards and it was only possibly to get a State Book record for the CrtCC for two of the cases in the sample that were dealt with on indictment. It was only possible to get access to 15 state files for the 30 infanticide cases disposed of on indictment in either court in this sample.

${ }^{56}$ Based on statistical information provided in GARC and by CSO. Between 1950 and 1996 murder was recorded as two separate categories - the murder of an infant aged under one year, and the murder of persons aged one year and over. There was also a separate category of infanticide. The figures given in the text are a combination of recorded infanticides and recorded infant murders; the majority of the latter category was either not prosecuted or were disposed of under the infanticide law. No information is available in the statistical sources consulted on the age of 'murder' victims since 1997.

${ }^{57}$ Two of these cases involved joint charges against the mother of the infant and, in one case, the infant's father (who was convicted of murder), and in the other, the infant's grandmother (who was otherwise disposed of).
} 
which involved a female perpetrator), the outcome is not known $(1977,1978,1980)$; and in one case involving a female perpetrator (1984) the charge was withdrawn. 
Table A: Disposals in cases where proceedings were taken against a woman* for the murder of an infant, 1950-2015 (information extracted from the GARC \& CSO Crime Statistics)

\begin{tabular}{|c|c|c|c|c|c|c|c|c|c|}
\hline \multirow[t]{3}{*}{ Year } & \multirow[t]{3}{*}{ Total } & \multirow{3}{*}{$\begin{array}{l}\text { Outcome } \\
\text { not } \\
\text { known }\end{array}$} & \multicolumn{3}{|c|}{ Murder } & \multicolumn{4}{|c|}{ Infanticide } \\
\hline & & & \multirow[t]{2}{*}{ Convict } & \multirow[t]{2}{*}{ Acqt } & \multirow{2}{*}{$\begin{array}{l}\text { O/W } \\
\text { disposed } \\
\text { of }\end{array}$} & \multicolumn{2}{|c|}{ Indictment } & \multirow[b]{2}{*}{ Sum* } & \multirow[b]{2}{*}{$\begin{array}{l}\text { O/W } \\
\text { disposed } \\
\text { of }\end{array}$} \\
\hline & & & & & & Conv/Plea & Acqt & & \\
\hline 1950 & 2 & - & - & - & - & 2 & - & - & - \\
\hline 1951 & 1 & - & - & - & - & 1 & - & - & - \\
\hline 1952 & 3 & - & - & - & - & 1 & 1 & 1 & - \\
\hline 1953 & 4 & - & - & - & - & 4 & - & - & - \\
\hline 1954 & 1 & - & - & - & - & 1 & - & - & - \\
\hline 1955 & 1 & - & - & - & - & 1 & - & - & - \\
\hline 1956 & 1 & - & - & - & - & 1 & - & - & - \\
\hline 1957 & 4 & - & - & - & - & 3 & 1 & - & - \\
\hline 1958 & 2 & - & - & - & - & - & - & 1 & 1 \\
\hline 1959 & 1 & - & - & - & - & 1 & - & - & - \\
\hline 1960 & 1 & - & - & - & - & 1 & - & - & - \\
\hline 1961 & 2 & - & - & - & 1 & - & 1 & - & - \\
\hline 1962 & 3 & - & - & - & - & 2 & 1 & - & - \\
\hline 1963 & 0 & - & - & - & - & - & - & - & - \\
\hline 1964 & 3 & - & - & - & - & 2 & - & 1 & - \\
\hline 1965 & 0 & - & - & - & - & - & - & - & - \\
\hline 1966 & 2 & - & - & - & - & 1 & - & 1 & - \\
\hline 1967 & 1 & - & - & - & - & 1 & - & - & - \\
\hline 1968 & 1 & - & - & - & - & 1 & - & - & - \\
\hline 1969 & 1 & - & - & - & - & 1 & - & - & - \\
\hline 1970 & 1 & - & - & - & - & 1 & - & - & - \\
\hline 1971 & 1 & - & - & - & - & 1 & - & - & - \\
\hline 1972 & 0 & - & - & - & - & - & - & - & - \\
\hline 1973 & 1 & - & - & - & - & - & - & 1 & - \\
\hline 1974 & 0 & - & - & - & - & - & - & - & - \\
\hline $\begin{array}{l}1975- \\
1979\end{array}$ & 2 & 2 & - & - & - & - & - & - & - \\
\hline $\begin{array}{l}\text { 1980- } \\
1989\end{array}$ & 2 & 1 & - & - & 1 & - & - & - & - \\
\hline $\begin{array}{l}1990- \\
2015\end{array}$ & 0 & - & - & - & - & - & - & - & - \\
\hline Total & 41 & 3 & 0 & 0 & 2 & 26 & 4 & 5 & 1 \\
\hline
\end{tabular}

*Summary disposal under the Infanticide Act 1949

Note in two cases $(1978,1980)$ the gender is not known. 


\section{(a) The disappearance of murder}

Table B summarises the outcome in the 36 cases disposed of under the Infanticide Act 1949.

Table B: Infanticide Disposals by Court and Outcome

\begin{tabular}{|c|c|c|c|c|c|c|c|}
\hline & & & ctment & & Summary $^{58}$ & $\mathbf{O} / \mathbf{W}$ & Total \\
\hline & & & $\mathrm{CCC}$ & Convict/PG & & & \\
\hline Trial & PG & Acquit & Convict/PG & & & & \\
\hline $\mathbf{0}$ & 11 & 4 & 12 & 3 & 5 & 1 & 36 \\
\hline
\end{tabular}

Due to gaps in the data it is not possible to say that no woman has been tried for or convicted of murdering her infant since the enactment of the infanticide statute. However, the statistical evidence available does indicate that murder was virtually abandoned as a trial and conviction option in these cases. All but two ( 94.7 per cent) of the cases in this sample were disposed of under the infanticide law, with 86 per cent of these resulting in a conviction, thus indicating that the requirements contained in the law did not preclude its use. ${ }^{59}$ Both district judges and prosecutors played an important role in ensuring women were not put on trial for murdering their infants. Where the district justice did not reduce the charge (at least 11 cases), the prosecution proved willing to treat this crime as infanticide, appearing to have always (or at least virtually always) accepted a guilty plea. The system also depended on accused women pleading guilty, and possibly defence lawyers also played a significant role. There were very few jury trials, and, in this regard, the approach taken

\footnotetext{
${ }^{58}$ The Criminal Justice Act 1951, section 3 made provision for persons appearing at the district court for preliminary examination of an indictable offence (with some exceptions) to be tried summarily at the District Court with the consent of the Attorney General. The Criminal Justice Act 1967, section 13, makes similar provision.

${ }_{59}^{59}$ See above at $\mathrm{n} 41$.
} 
demonstrates a consolidation among criminal justice professionals of the socially normative expectation that women who killed their babies at birth should not be treated as murderers.

This is not to say that social norms alone determined the outcome. As was the case prior to 1949, these filtered through the professional norms of criminal justice personnel. For example, prosecutors were probably also oriented to secure convictions, and to do so in an efficient manner, something which would have encouraged them to accept infanticide pleas where they anticipated juror reluctance to convict. District justices who reduced murder charges may have been similarly motivated. Further, the fact that district justices did not always amend the charge indicates that at least among that group of criminal justice professionals it was not consistently agreed that 'infanticide' could never be 'murder'. Nonetheless, the evidence demonstrates that the system as a whole operated on the basis that maternal infant murder was 'infanticide' not 'murder', and, as such, warranted a lenient outcome. Given that most of the cases in this sample involved newborn victims, arguably the 'appropriate' case that law reformers had in mind when the infanticide law was drafted and enacted, this is perhaps not surprising, but there were at least four cases involving the murder of older infants by married women (a 12-day-old; a four-month-old, and two 11month-old victims), where the Irish state was equally willing to use the infanticide law by accepting a plea.

As outlined in the previous section, even prior to the enactment of the infanticide legislation, criminal justice personnel had agreed, or at least accepted, that infanticide, especially of newborn infants, was not murder. After 1949, the label may have changed from 'manslaughter' or 'concealment of birth' to 'infanticide', but the 1949 law did not in essence affect the response. Sentencing practice also largely reflected the approach taken prior to the 
reform; the majority of women were given a suspended prison sentence. ${ }^{60}$ It would seem from this analysis that social norms continued to influence legal practice, and that the infanticide law operated as intended - to gain a conviction for an offence other than murder through a more efficient, humane and rational process. ${ }^{61}$ As will be demonstrated in the following section, the role of social norms in shaping the implementation of the infanticide statute is most evident in the way the medical rationale was construed and employed.

(b) Social norms in interpreting the medical rationale: 'any woman giving birth alone and unaided is likely to be in a disturbed state of mind'

As outlined above, the infanticide statute was framed according to legal norms regarding the individualisation of criminal responsibility which required mitigation based on mental illness, not social stress. However, the statute embodied mitigation based on social norms, involving an understanding of the social circumstances of infanticide and the likely mental state of the accused in light of these circumstances. It was, therefore, never intended that the law would operate in a narrow way: social mitigation was to be considered. ${ }^{62}$ In terms of how infanticide legislation has operated in practice, in England, the medical rationale has been widely interpreted to incorporate social mitigation and as such acts largely as a device to facilitate lenient treatment. ${ }^{63}$ The data in this study shows that the Irish courts have also taken a wide approach: the infanticide law was used in 95 per cent of the cases in this sample where proceedings were initiated against a woman for the murder of her infant. The

\footnotetext{
${ }^{60}$ Brennan, above n 3.

${ }^{61}$ See Brennan, above $\mathrm{n} 6$, for further detail on the reasons for the enactment of the infanticide statute.

${ }^{62}$ See above n 47-51.

${ }^{63}$ RD Mackay 'The Consequences of Killing Very Young Children' (1993) Criminal Law Review 21-30 at 29
} 
evidence from the state files in a sample of 15 cases (the only cases where this record was available) further demonstrates the generous application of the medical rationale. ${ }^{64}$

In six cases, the infanticide law appears to have been used without any medical evidence to support the mental disturbance requirement. The district justice reduced the charge in four and forwarded the accused for trial for infanticide, although none of the documents in the state file relating to the evidence given at the preliminary hearing make any reference to the accused's mental state. In the two other cases, an infanticide plea was accepted at the CCC. Each of the six cases involved an unmarried woman who had concealed her pregnancy and given birth in secret; all but one had given birth alone and none had given birth with medical assistance. ${ }^{65}$ As such, these were the kind of cases where the infanticide law was supposed to apply, and where a mental disturbance was likely to be presumed according to social norms in relation to how this offender was understood, and ought to be treated, in light of the circumstances involved.

In three further cases, the file did include some reference to the accused's mental state, but the evidence did not support the infanticide requirements. ${ }^{66}$ The charge was not reduced in any of these cases, but an infanticide plea was accepted at the CCC. One of these women had been diagnosed with depression, the only woman in the sample to be diagnosed with a specific mental disorder and to have received treatment for that condition. However, the medical witness at the district court refused to confirm that her illness was connected with

\footnotetext{
${ }^{64}$ The evidence available in state files is limited to what witnesses said in their depositions, or during crossexamination, at the district court, and any comments made by the medical officer while the accused was held on remand. However, in terms of what information was available to district justices when making a decision about whether to reduce the charge to infanticide, they were reliant on what witnesses said in their depositions. In cases where the accused was sent for trial for murder it is possible that other evidence was available by that time, supplied by the defence, which is not included in the state file.

${ }^{65}$ NAI: SFCCC, ID/51/2 (Limerick, 1953: two cases); SFCrtCCC, IC/98/27 (Monaghan, 1953); SFCrtCC, V15/13/12 (Galway, 1953); SFCrtCC, IC/14/129 (Donegal, 1959); SFCrtCC V4B/12/17 (Louth, 1969).

${ }^{66}$ NAI: SFCCC V15/14/47 (Kildare, 1954); SFCCC V15/14/45 (Carlow, 1954); SFCCC IC/17/58 (Donegal, 1966).
} 
childbirth or that she had been mentally disturbed at the time of birth. ${ }^{67}$ The accused in that case had killed six newborn babies over a number of years to conceal an extra-marital relationship. The two remaining cases did not involve newborn victims, though in one a woman had killed her twelve-day-old son as a result of distress over the fact that her estranged husband denied paternity of the child. ${ }^{68}$ Overall, none of the cases involved the typical infanticide facts, something which may explain the justice's decision to not reduce the charge. These cases were not those were social norms traditionally claimed a lenient response. Nonetheless, the decision to accept an infanticide plea arguably reflects both practical expediency (in anticipation that a jury would likely sympathise with the offender and reject murder), and a belief, or at least an acceptance, that these women also warranted a compassionate criminal sanction.

In the remaining six cases, medical evidence was given at the district court which tended to support the use of the infanticide law by at least making some reference to the requirements in the statute, though the evidence paid lip service to the infanticide criterion. This evidence often came from the state pathologist and/or a medical doctor who had examined the accused soon after birth, and who had been asked in cross-examination about her mental state at the time of birth. These witnesses provided rather generic and speculative responses, which is not surprising given that they were making a deposition on behalf of the state, were usually not a mental health expert, and sometimes had not had an opportunity to examine the accused. Many of these statements tended to evince a presumption of mental disturbance linked to the fact that the accused had given birth alone and had killed the child at birth giving birth alone was itself sufficient to presume a mental disturbance, and killing the

\footnotetext{
${ }^{67}$ NAI: SFCCC V15/14/47 (Kildare, 1954).

${ }^{68}$ SFCCC V15/14/45 (Carlow, 1954).
} 
infant was the ultimate manifestation of this. ${ }^{69}$ In four of these cases the charge was reduced to infanticide at the district court.

For example, in one case the state pathologist said that 'any woman giving birth alone and unaided is likely to be in a disturbed state of mind at the time and shortly afterwards' ${ }^{70}$ Interestingly, the charge was not reduced, despite the fact that the circumstances reflected those of other typical infanticide cases: the accused had given birth alone, following a concealed pregnancy, in the bathroom at her lodgings and had stuffed toilet paper into the baby's mouth to stop it from crying. ${ }^{71}$ She pleaded guilty to infanticide. ${ }^{72}$ In another case, where a domestic servant was found collapsed on her bedroom floor with her dead infant one morning, the state pathologist stated that he "would expect a girl like the accused to be in a frenzied state after giving birth alone' ${ }^{73}$ In another case, the accused had given birth in her bedroom at her parent's home and thrown the baby out of the window. The doctor who examined her soon after birth said: 'At the time of the birth of the child [her] mental condition ... was probably abnormal. It is my opinion that she was probably mentally disturbed by reason of the birth of the child.' A local midwife who had attended the accused shortly after the birth provided a rather vivid account of the accused's condition: 'Her ... eyes were standing outside her head ... and her mouth was foaming'. She later added on cross-examination: 'It was one of the most terrifying experience[s] I ever witnessed.... She was in a very overwrought condition and highly hysterical. I don't think she realised that she was to have a baby'. ${ }^{74}$ In another case, involving an 18 -year-old woman who gave birth alone in the toilet in the bathroom of her parent's home and then stabbed the baby with

\footnotetext{
${ }^{69}$ See Loughnan, above n 48, 692.

${ }^{70}$ NAI: SFCCC ID/2/162 (Dublin, 1964).

${ }^{71}$ Ibid.

72 NAI: SBCCC, ID/2/146A (1962 - July 1964). In another case, where the state pathologist made the same comment and where the accused's own doctor indicated that she had been in a disturbed mental state, the charge was reduced. See NAI: SFCrtCC ID/2/162 (Tipperary, 1957).

${ }^{73}$ NAI: SFCrtCC, V14/21/21 (Meath, 1961).

${ }^{74}$ NAI: SFCrtCC, V7/16/6 (Kerry, 1957).
} 
scissors, a consultant gynaecologist who examined her said: 'It is feasible that there would be mental disturbance after childbirth in such circumstances as this.... The destruction of an infant within an hour or two of birth or even longer by its mother would lead one to conclude that her mental balance was disturbed' ${ }^{75}$

In the final case, medical evidence was given at the district court which could have been taken to justify a reduced charge, but the accused was sent for trial for murder. This case did not reflect the typical newborn scenario as it involved a married woman who had killed her 11-month-old son. One of the medical witnesses deposed that the accused had experienced a temporary mental disturbance at the time of the killing that was linked to the physical consequences of childbirth. However, another, more experienced witness, refused to give his views on her mental state without having the opportunity to further examine her. Again, the fact that this was an atypical case, one which did not fall within the category of cases where social norms tended to seek a lenient outcome, was likely a key factor in the decision to not reduce the charge. Nonetheless, the accused's plea of guilty to infanticide was accepted, and, like most of the other women in this sample, she was given a short suspended prison sentence. $^{76}$

Overall, despite adopting the legally normative approach of individualized responsibility which allowed for mitigation based on mental illness, not social stressors, the law operated in practice according to social norms which expected mitigation based on the circumstances involved, including that of recent childbirth. Particularly in the context of the typical concealed birth scenario, the legislation applied on the basis of a presumption of mental disturbance in the circumstances involved. Medical diagnosis of a specific mental disorder, particularly one that was linked to childbirth or lactation, was not required. ${ }^{77}$ When medical

\footnotetext{
${ }^{75}$ NAI: SFCrtCC, V6/32/6 (Galway, 1954).

${ }^{76}$ Mayo, 1971. File not accessible at NAI; file obtained directly from CCC.

${ }^{77}$ This has recently been recognised by the Canadian Supreme Court: $R v$ Borowiec, 2016 SCC 11.
} 
'expertise' was called on, these witnesses themselves often employed lay assumptions rather than medical knowledge. It was social, rather than medical or legal, norms that determined the scope of the infanticide law.

In summary, this section has demonstrated that the infanticide offence effectively replaced murder in the second half of the twentieth century. The 1949 infanticide law operated as it was meant to and criminal justice agents worked to ensure that it was used in 'appropriate cases'. ${ }^{78}$ However, it was not the law that established this virtual separation of maternal infant murder from other murders. The history of the response to this crime in the decades prior to the enactment of the 1949 statute shows that the criminal justice system had long treated the killing of infants by their mothers as something other than murder. In this sense, the infanticide law did not shape the criminal justice response, though it may have further entrenched the disposition to view this crime as falling outside the scope of 'ordinary' murder. Social norms required a lenient conviction, and the infanticide law, which embodied these norms, was generously employed to facilitate this.

\section{The Disappearance of Infanticide: A disinclination to prosecute}

Whilst not prosecuting this offence has always been a significant part of the response to it (44 per cent of all reported cases since 1950 were not prosecuted), it is apparent that this approach has become the more prevalent in recent decades. Since the 1970s/1980s, prosecutions against women in reported incidents of infanticide have declined, and there appear to have been no prosecutions against women for murder/infanticide since $1984 .^{79}$

\footnotetext{
${ }^{78}$ See above at $\mathrm{n} 52$.

${ }^{79}$ See above Table A and accompanying text. It is possible that there have been instances of maternal infant murder during this period where proceedings were taken and the offender was disposed of under an offence other than infanticide, such as murder, manslaughter or concealment of birth; see above n 57.
} 
Although there may be evidential issues which preclude prosecution, particularly in cases of newborn infanticide, ${ }^{80}$ the consistent unwillingness to prosecute in recent decades indicates that other factors are involved. It appears that there has been a shift in practice whereby state authorities, who in the past sought a compassionate criminal sanction, now do not favour criminal prosecution at all. This change in practice has taken place despite the fact that the criminal law with respect to infanticide has remained largely unaltered. ${ }^{81}$ What has changed, however, is the social context.

From the 1960s, and particularly during the 1970s and 1980s, Ireland slowly began to liberalise, ${ }^{82}$ something which had an impact on the incidence of newborn infanticide. Since the 1970s, the offence of infanticide has diminished to the extent that it is now practically non-existent: there were 12 recorded cases in the 1970s, and five cases each during the 1980s and 1990s. Only one case of infanticide is recorded for the period 2000 to 2015 , inclusive. ${ }^{83}$ Given the historical link between infanticide and illegitimacy, a number of factors, all of which are connected with improvements in women's rights in recent decades, plausibly account for this decline, including: the availability of legalised abortion in Britain since 1967 , at least for those who could afford it; ${ }^{84}$ increasing access to contraception and contraceptive advice, and the eventual legalisation of contraception; ${ }^{85}$ the introduction of the unmarried mother's allowance in $1973 ;^{86}$ and a significant shift in cultural attitudes to unmarried motherhood. ${ }^{87}$ Kilcommins et al observe that the 'disappearance of infanticide

\footnotetext{
${ }^{80} \mathrm{C}$ Alder and K Polk Child Victims of Homicide (Cambridge: Cambridge University Press, 2001) p 44.

${ }^{81}$ Except with respect to the amendment made in 2006; see above $\mathrm{n} 40$.

${ }^{82}$ See generally, Inglis, above $\mathrm{n} 21$, chs 8-9.

${ }^{83}$ See GARC, 1970-2005; CSO (2006-2015).

${ }^{84}$ Between January 1980 and December 2014, 163,514 women and girls travelled from the Republic of Ireland to England and Wales to obtain an abortion: see https://www.ifpa.ie/Hot-Topics/Abortion/Statistics, accessed 3 September 2015.

${ }^{85}$ See generally C Hug The Politics of Sexual Morality in Ireland (London: Macmillan Press, 1999) p 86-91. For example, see Health (Family Planning) Act 1979, sections 4, 5 \& 13; the Health (Family Planning) Amendment Act 1985, section 2; The Health (Family Planning) Amendment Act 1992.

${ }^{86}$ Social Welfare Act 1973 , section 8.

${ }^{87}$ S Kilcommins, I O'Donnell, E O'Sullivan, and B Vaughan Crime Punishment and the Search for Order in Ireland (Dublin: Institute of Public Administration, 2004) p 117.
} 
reflects a changing social and moral environment', noting in particular the fact that unmarried motherhood no longer attracts social disgrace nor the prospect of institutional confinement. $^{88}$

The fact that infanticide is now an exceptionally rare event may have affected the criminal justice response, particularly with regard to the perceived need to prosecute. Whereas in the past the relatively frequent occurrence of infanticide arguably created an incentive to pursue criminal charges to protect and vindicate infant life, on a symbolic level at least, and to deter others from this crime, where the crime is committed infrequently possibly there is more scope to exercise discretion to not initiate proceedings. It may not be in the 'public interest' to prosecute, particularly where sympathy for the perpetrator indicates that she should be treated leniently. More recent guidance for prosecutors indicates that one factor to consider when determining public interest is the prevalence of the offence and the need for both general and specific deterrence. ${ }^{89}$ Finally, it is also worth noting that the decline in infanticide and infanticide prosecutions took place at a time when other kinds of violent crime increased, particularly in the context of the conflict in Northern Ireland. ${ }^{90}$ With this rise in violent and dangerous offending, possibly infanticide appeared to warrant less attention. However, in cases of homicide, particularly where the victim is a child, it seems unlikely that pragmatic calculations of public interest based on the incidence of the crime and the need to deter would be decisive factors in the decision to prosecute.

Dooley in his study of homicide in Ireland between 1972 and 1991 also observed a hesitancy to prosecute infanticide. ${ }^{91}$ Out of nine infanticide cases in his sample, seven were not

\footnotetext{
${ }^{88}$ Ibid.

${ }^{89}$ Director of Public Prosecutions, Guidelines for Prosecutors (2010, Revised), para. 4.22(b), available at: https://www.dppireland.ie/filestore/documents/GUIDELINES___Revised_NOV_2010_eng.pdf, accessed 7 Dec 2015.

${ }^{90}$ Inglis, above n 21, 121; Kilcommins et al, above n 87, p 67-68.

${ }^{91}$ E Dooley Homicide in Ireland, 1972-1991 (Dublin: Department of Justice, Dublin Stationery Office, 1995) p 28.
} 
charged or a nolle prosequi was entered, despite the fact that there was no apparent dispute that the mother had a mental disorder which would have met the infanticide criteria. ${ }^{92}$ In a subsequent study covering the period 1992 to 1996, he refers to two infanticide cases (the only two cases during that period) where the prosecution authorities and the Gardaí were 'sympathetic to the indication that the precipitator of the event was acute panic surrounding an unexpected and unsupported birth'. ${ }^{93}$ Thus, whilst humanitarian sentiment for women who killed their infants at a concealed birth in the past lead to lenient criminal disposals, this now seems to manifest itself in a disinclination to prosecute this offender at all. The question is why does sympathy now result in a non-criminal response? In this regard, there were two incidents in 1984 which, in the context of a wider cultural transition away from traditional and conservative ideologies, may help to explain this shift away from criminalising women who kill their infants. Both events publicly exposed in an uncompromising way the experiences of women who conceal their pregnancies and give birth alone, and may have affected social norms with regard to how women who kill their babies in the context of a concealed birth should be treated under the law.

In January 1984, Ann Lovett, a teenage girl, was found in a Grotto of the Virgin Mary in Granard, Co Longford. Ann had given birth to an infant in the Grotto that afternoon following a concealed pregnancy. Both Ann and her baby died as a consequence of this unassisted birth. ${ }^{94}$ Some months later, in April, a newborn baby was found with several stab wounds washed up on a beach in Cahirciveen, Co Kerry. The Garda investigation lead to the arrest of Joanna Hayes, a local unmarried woman, already mother to one child, and who was suspected of having recently given birth to a second baby. Hayes and her family signed

\footnotetext{
92 Ibid.

${ }^{93}$ E Dooley, Homicide in Ireland, $1992-1996$ (Dublin: Department of Justice, Dublin Stationery Office, 2001) p 18. Information in the GARC for this period indicate that no infanticide prosecutions were taken.

${ }^{94}$ See generally, D Ferriter Occasions of Sin: Sex and Society in Modern Ireland (London: Profile Books, 2009) pp 524-525; MJ Maguire 'The Changing Face of Catholic Ireland: Conservatism and Liberalism in the Ann Lovett and Kerry Babies Scandals’'(2001) 27(2) Feminist Studies 335-358.
} 
confessions admitting that the baby found on the beach was Joanne's, that she had killed it, and that her siblings had then thrown the body into the sea. However, Joanne had originally confessed to giving birth to a baby and disposing of the body on the family farm. Scientific tests eventually established that Hayes was not the mother of the baby found at Cahirciveen, and the murder charge against her was withdrawn. The mother of that baby has never been identified. Hayes was not charged with any offence connected with the baby found on the farm. ${ }^{95}$

The Lovett and Hayes cases occurred at a time of significant social turmoil as the nation grappled with liberalisation - a socialisation process involving a battle between the old catholic conservative Ireland and the newly emerging secular and liberal society. ${ }^{96}$ These cases generated much media coverage, drawing public attention to issues that in the past had remained hidden, helping to challenge the nation's own idealised image of itself, and they had a significant impact on Irish society, including wider attitudes towards unmarried mothers. ${ }^{97}$ Maguire argues that these cases 'contribute[d] to a change in public attitudes towards unmarried motherhood' and that they 'forced Irish society to confront in a very public and self-conscious way, issues that had long been considered unsuitable for public discussion ${ }^{98}$ In particular, both cases highlighted concealed pregnancy, the vulnerability of women in these situations, and the risk posed to both mother and baby. The Kerry Babies case also demonstrated the potentially oppressive consequences of the misuse of state power against vulnerable women in this situation. A Tribunal of Enquiry established to investigate the Garda handling of the Kerry Babies case resulted in much public sympathy for Joanne Hayes who broke down on several occasions under the intensity of the examination and at

\footnotetext{
${ }^{95}$ For an account of the investigation of this crime and the legal proceedings that followed, see Inglis, above $\mathrm{n}$ 21 , chs 2-7.

${ }^{96}$ Ibid. ch. 10.

${ }_{97}^{97}$ See generally, Inglis, above n 21, passim; Ferriter, above n 94, pp 524-527; Maguire, above n 94.

${ }^{98}$ Maguire, above n 94, 353.
} 
one point required sedation. ${ }^{99}$ As Ferriter observes, the case 'was one of the most emotive episodes of modern Irish history, evoking sympathy and anger about the dissection of a woman's private life by an all-male inquiry.... 100

Inglis notes that the harsh treatment of Hayes by the Tribunal of Enquiry, which contrasts with the outpouring of public support and sympathy that she received, demonstrated a gap between the state and the public will. ${ }^{101} \mathrm{He}$ argues that the case reflects the confrontation between the ideologies of old conservative catholic Ireland, and the new liberal, modern and secular culture that had begun to emerge. ${ }^{102}$ The public support that Hayes received, albeit not in the context of a criminal trial, may have indicated there was little public appetite for criminal proceedings in infanticide cases. In this regard, although prosecutions for infanticide had already begun to decline prior to 1984 , it is telling that there appear to have been no prosecutions against women for infanticide since the murder charge against Joanne Hayes was withdrawn. ${ }^{103}$ Is it possible, in the wider context of liberalisation, that the lasting impact of the Kerry Babies and the Ann Lovett cases on the Irish psyche meant that it became wholly objectionable to use the potentially oppressive force of the law against women who killed their infants at a concealed birth? As already observed, whilst criminal justice actors are likely to hold different viewpoints, in their professional capacity, compared to the rest of the lay population, ${ }^{104}$ it is unlikely that Gardaí and prosecutors were wholly untouched by the significant cultural changes that took place in Ireland from the 1960s onwards, and by the dramatic incidents of 1984. Certainly, the history of infanticide shows that wider social norms will impact on criminal justice practice, whether because

\footnotetext{
${ }^{99}$ Inglis, above n 21; Ferriter, above n 94, p 526; Maguire, above n 94, 348-51.

${ }^{100}$ Ferriter, above n 94, p. 526.

${ }^{101}$ Inglis, above $\mathrm{n} 21, \mathrm{p} 187$.

102 Ibid. p 3 and passim.

${ }^{103}$ There is a possibility that women have been proceeded against for other offences; see above n 82 .

${ }^{104}$ See above text at n 21-22.
} 
professionals agree with normative expectations about the appropriate response or accept that it is impractical to act contrary to this.

\section{Conclusion}

This analysis has demonstrated the vital role of social norms in the legal response to infanticide in Ireland from the time of independence from Britain and into the twenty-first century. Prior to the enactment of a specific infanticide law, lenient treatment of women who killed their illegitimate babies, usually in the context of a concealed birth, was the expected response according to social, rather than legal, norms, and the law was ignored or manipulated to secure the desired outcome. The wider social context and how infanticide, and the infanticide offender, was understood in that context, determined the outcome. This entailed a general agreement that 'unfortunate' women and 'young girls' who concealed their pregnancies and killed their illegitimate babies at or soon after birth, should be given a compassionate criminal sanction.

The social understanding of infanticide was embedded in the 1949 Act which formalised and rationalised the agreed preference for lenient treatment, allowing for conviction for 'infanticide' not 'murder' and granting judges much flexibility as to sentence. The infanticide law adopted a mitigation framework which did two things. First, it embodied the socially normative understanding of infanticide which sought lenient treatment due to the social circumstances of her crime and the presumed impact of these circumstances on her mental state, particularly in the context of a concealed 'illegitimate' pregnancy and unassisted birth. Second, it transcribed this socially normative conception of infanticide into legal doctrine which allowed for lenient treatment whilst adhering to criminal law norms regarding individualized responsibility. The evidence in this study shows that the law was applied according to social norms, though professional expectations with regard to securing 
punishment in an efficient manner also likely played a part. The law was effectively a device to allow for a compassionate criminal sanction where professional norms sought conviction but where social norms expected lenience due to the circumstances involved. It did not require a medically diagnosed mental illness; nor did it restrict consideration of mitigation to the impact of the biological or physical effects of birth on the mental state of the woman. This history of the infanticide legislation, and how it has been implemented in the courts, demonstrates the importance of taking account of the sociology of legal provisions, particularly a socio-historical view of the law. The history of the crime of infanticide, the social context in which it took place, the criminal justice response to it, and the enactment of the infanticide legislation, allow for a fuller understanding of the true meaning, purpose and scope of infanticide laws.

This study also shows how as the social context shifts, so too may the legal response to the crime of infanticide. A more liberal, tolerant, and open Irish society may have contributed to the effective decriminalisation of the now rare crime of infanticide. However, this is not to suggest that a more liberal society will necessarily produce more lenient treatment of women who kill their newborn babies. Thus, whilst the Law Reform Commission of Western Australia recently observed that cases of newborn infanticide are regularly not prosecuted in that jurisdiction, noting empathy among prosecutors for this offender, ${ }^{105}$ prosecutions for newborn infanticide have been taken in England in recent decades. ${ }^{106}$ Indeed, in 2017 in Preston, England, a woman was convicted of murdering her newborn infant in the context of a concealed birth, and sentenced to a minimum of 20 years in

\footnotetext{
${ }^{105}$ Law Reform Commission of Western Australia, Review of the Law of Homicide (Final Report, Project 97, 2007), pp. 104, 112-113, available at: http://www.lrc.justice.wa.gov.au/_files/P97-ch03.pdf, accessed 4 December 2015.

${ }^{106}$ RD Mackay, 'Infanticide and Related Diminished Responsibility Manslaughters: An Empirical Study' in Law Commission, Murder, Manslaughter and Infanticide (Law Com no. 304, 2006) Appendix D, pp 192-243 at 196 Table $3 b$.
} 
prison. ${ }^{107}$ Kramar has suggested that in recent decades a more punitive attitude to infanticide has emerged in Canada. She identifies a number of factors that contributed to this shift in approach, including a change in attitude to the offender. ${ }^{108}$ Kramar argues that whereas in the past Canadian women who killed their newborn illegitimate babies following a concealed pregnancy were viewed sympathetically, social changes in the second half of the twentieth century which granted women greater control over their fertility and which destigmatised unmarried motherhood challenged the idea of the unwanted baby and helped to shift humanitarian sentiment away from the mother in cases of infanticide. ${ }^{109}$ In other words, a woman's failure to exercise her supposed autonomy to control her fertility and to prevent or end an unwanted pregnancy before the point of birth means she may be viewed as being more blameworthy for her situation (and ultimately for her crime) than she was in the past when killing a newborn baby in the context of a concealed birth may have been viewed as an 'understandable' reaction to an unwed pregnancy. ${ }^{110}$ This is not to say that offenders in Canada are never treated sympathetically. Indeed, the recent Supreme Court decision in Borowiec on the meaning of the medical rationale would indicate that the courts still view infanticide as being different to other killings. ${ }^{111}$ It can be suggested, however, that the experience in Canada indicates that attitudes to this offender may vary, and that liberalization does not necessarily equate with increased lenience.

The reasons for differences in approach between jurisdictions are undoubtedly complex, but socially and culturally specific factors, including the timing, nature, pace and degree of liberalisation, and women's equality and reproductive rights, may play a part in how contemporary societies respond to newborn child killing. Where women have gained

\footnotetext{
${ }^{107}$ http://www.bbc.co.uk/news/uk-england-lancashire-40330268, accessed 27 June 2017.

108 Kramar above n 20, chs 4-6.

109 Ibid.

${ }^{110}$ Ibid. ch 4, and p 188.

${ }^{111}$ Above $\mathrm{n} 49$.
} 
significant reproductive rights, they may no longer be viewed sympathetically when they kill their newborn illegitimate infants. However, whilst Ireland has left behind much of its conservative past, in the context of women's reproductive rights it has an exceptionally restrictive abortion regime. ${ }^{112}$ In Canada, women seem to have lost their status as sympathetic victim as a consequence of achieving reproductive rights, including the decriminalization of abortion. ${ }^{113}$ If Irish law on abortion were to liberalise, would attitudes to the infanticide offender similarly shift?

This story of infanticide in Ireland, which sees this crime change from being a not uncommon occurrence that was punished, but not harshly, to an exceptional event which has not been punished in over four decades, provides a good example of how as society changes so too will the nature of criminality and ideas about the 'appropriate' response to certain behaviours. The criminal law will either be practised according to prevailing social norms, or it will be modified, repealed, or replaced to accommodate social expectations about the role of the criminal law and appropriate punishment. There are many other examples which highlight the criminal law's susceptibility to changing social conditions, such as the decriminalization of homosexuality, the criminalization of marital rape, and changes in the scope of sexual offences.

In conclusion, the Infanticide Act 1949 was enacted in a particular socio-historical context to deal with a specific kind of killing, that of newborn child murder. The changed social, cultural and legal context, the consequent disappearance of infanticide, and the fact that this crime has not been prosecuted in recent decades, raises the question: has the time has come

\footnotetext{
${ }^{112}$ Article 40.3.3 of the Irish Constitution grants the 'unborn' an equal right to life to that of the pregnant woman, and abortion is only available where there is real and substantial risk to the life of the woman (including suicide: The Attorney General v X [1992] 1 I.R. 1), but not her health: see the Eight Amendment of the Constitution Act 1983, and the Protection of Life During Pregnancy Act 2013.

${ }^{113}$ R v Morgentaler [1988] 1 SCR 30. However, there are, in practice, numerous barriers to accessing medical abortions: see J Downie \& C Nassar 'Barriers to Access to Abortion through a Legal Lens' (2007) 15 Health Law Journal 143-73.
} 
to re-evaluate the need for this unique and gendered law? This is a question, not only for Ireland, but also other jurisdictions with a similar history and law. This article does not propose to explore this question, except to note that the Irish legislature appears to see a continued need for the 1949 law, having amended the medical mitigation framework in 2006, supposedly to reflect current medical thinking. ${ }^{114}$ Elsewhere, a number of law reform bodies have recently recommended retention of their infanticide statutes. Justifications for retaining this law have generally focused on its practical benefits, the risk that if abolished women would be convicted of murder where this is not warranted, and the unique nature of this offence. ${ }^{115}$ For example, the New South Wales Law Reform Commission noted that the infanticide law allows for an 'appropriate and compassionate criminal law response to the complex and tragic set of circumstances that may result in a mother killing her infant'.116 The Law Commission in England and Wales recently concluded that the Infanticide Act 1938, which poses few problems in practice, is 'a practicable legal solution to a particular set of circumstances'. ${ }^{117}$ Bearing in mind the history behind infanticide statutes, particularly the difficulties that arose in criminal justice practice when infanticide was dealt with as ordinary homicide, the conclusions of these law reform bodies suggest that the practical benefits of this law mean we should not hasten to abandon it.

\footnotetext{
${ }^{114}$ See above $\mathrm{n} 40$; Further detail in K Brennan, 'Beyond the Medical Model: A Rationale for Infanticide Legislation' 58 (2007) Northern Ireland Legal Quarterly 505-535 at 512-513.

${ }^{115}$ See generally, Victoria Law Reform Commission, Defences to Homicide: Final Report (Melbourne, 2004), para. 6.16-6.25, available at http://www.lawreform.vic.gov.au/sites/default/files/FinalReport.pdf; New South Wales Law Reform Commission, People with Cognitive and Mental Health Impairments in the Criminal Justice System: Criminal Responsibility and Consequences (report no. 138, 2013), para. 5.35-44, 5.47-50, available at: http://www.lawreform.justice.nsw.gov.au/agdbasev7wr/lrc/documents/pdf/report_83.pdf; Law Commission, Murder, Manslaughter and Infanticide (Law Com no. 304, 2006), para. 8.3, 8.7-12, 8.36-39, available at https://www.gov.uk/government/uploads/system/uploads/attachment_data/file/228782/0030.pdf. ${ }^{116}$ Ibid. para. 5.49.

117 Above n 110, para. 8.3.
} 